\title{
The development of SSR markers based on RNA-sequencing and its validation between and within Carex L. species
}

Lingyun Liu', Xifeng Fan², Penghui Tan³, Juying Wu², Hui Zhang ${ }^{2}$, Chao Han², Chao Chen², Lulu Xun ${ }^{4}$, Weier Guo ${ }^{5}$, Zhihui Chang ${ }^{1 *}$ and Ke Teng ${ }^{2^{*}}$ (D)

\begin{abstract}
Background: Carex L. is one of the largest genera in the Cyperaceae family and an important vascular plant in the ecosystem. However, the genetic background of Carex is complex and the classification is not clear. In order to investigate the gene function annotation of Carex, RNA-sequencing analysis was performed. Simple sequence repeats (SSRs) were generated based on the Illumina data and then were utilized to investigate the genetic characteristics of the 79 Carex germplasms.

Results: In this study, 36,403 unigenes with a total length of 41,724,615 bp were obtained and annotated based on $\mathrm{GO}, \mathrm{KOG}, \mathrm{KEGG}$, NR databases. The results provide a theoretical basis for gene function exploration. Out of 8776 SSRs, 96 pairs of primers were randomly selected. One hundred eighty polymorphic bands were amplified with a polymorphism rate of $100 \%$ based on 42 pairs of primers with higher polymorphism levels. The average band number was 4.3 per primer, the average distance value was 0.548 , and the polymorphic information content was ranged from 0.133 to 0.494 . The number of observed alleles ( $\mathrm{Na}$ ), effective alleles (Ne), Nei's (1973) gene diversity $(\mathrm{H})$, and the Shannon information index (I) were 2.000, 1.376, 0.243, and 0.391, respectively. NJ clustering divided into three groups and the accessions from New Zealand showed a similar genetic attribute and clustered into one group. UPGMA and PCoA analysis also revealed the same result. The analysis of molecular variance (AMOVA) revealed a superior genetic diversity within accessions than between accessions based on geographic origin cluster and NJ cluster. What's more, the fingerprints of 79 Carex species are established in this study. Different combinations of primer pairs can be used to identify multiple Carex at one time, which overcomes the difficulties of traditional identification methods.
\end{abstract}

Conclusions: The transcriptomic analysis shed new light on the function categories from the annotated genes and will facilitate future gene functional studies. The genetic characteristics analysis indicated that gene flow was extensive among 79 Carex species. These markers can be used to investigate the evolutionary history of Carex and related species, as well as to serve as a guide in future breeding projects.

Keywords: Carex L., Illumina RNA-sequencing, Gene function annotation, SSR marker, Marker polymorphism, Genetic cluster

\footnotetext{
* Correspondence: changzh@bjfu.edu.cn; tengke.123@163.com

${ }^{1}$ College of Grassland Science, Beijing Forestry University, Beijing 100083,

China

${ }^{2}$ Beijing Research and Development Center for Grass and Environment, Beijing Academy of Agriculture and Forestry Sciences, Beijing 100097, China

Full list of author information is available at the end of the article
}

(c) The Author(s). 2021 Open Access This article is licensed under a Creative Commons Attribution 4.0 International License, which permits use, sharing, adaptation, distribution and reproduction in any medium or format, as long as you give appropriate credit to the original author(s) and the source, provide a link to the Creative Commons licence, and indicate if changes were made. The images or other third party material in this article are included in the article's Creative Commons licence, unless indicated otherwise in a credit line to the material. If material is not included in the article's Creative Commons licence and your intended use is not permitted by statutory regulation or exceeds the permitted use, you will need to obtain permission directly from the copyright holder. To view a copy of this licence, visit http://creativecommons.org/licenses/by/4.0/ The Creative Commons Public Domain Dedication waiver (http://creativecommons.org/publicdomain/zero/1.0/) applies to the data made available in this article, unless otherwise stated in a credit line to the data. 


\section{Background}

The genus Carex L. belongs to the Cyperaceae family and is an enormous genus. It is one of the most vital genera of vascular plants in the environment [1], with more than 2000 species widespread all over the world [2] and nearly 500 species in China [3]. Carex species are widely used as a ground cover for home lawns as well as for slope stabilization in many parts of the world because of cold and drought tolerance [4], trample resistance, and high ornamental value $[5,6]$.

Previous studies focused on geographical distribution, phylogeography, and origin area of Carex. Benítez-Benítez et al. [7] found obvious genetic differentiation between two Carex sister species in the western Mediterranean, and pointed out that geographic barriers played dominant role in restricting gene flow. Míguez et al. [8] revealed late Miocene-Pliocene aridification of the Mediterranean shaped the phylogeography of Carex sect. Rhynchocystis. Martín-Bravo et al. [9] proved that Carex originated in the late Eocene in East Asia which has a productive diversity of Carex. Previous studies clarified the phylogenetic structure of Carex into at least four major clades, including Siderostictae clade, core Carex, Vignea, and Caricoid clade [10]. However, a supermatrix analysis combining ETS, ITS and matK DNA regions indicated that over-reliance on morphological characters was inappropriate for the delimitation of natural groups [11].

Molecular markers are powerful tools for genetic diversity analysis which is the basis of accelerating plant breeding process. Currently, commonly used molecular markers mainly include ISSR, RAPD, RFLP, AFLP, SSR, and SRAP [12]. Due to the advantages of abundant, multi-allelic, highly polymorphic and codominant, simple repeat sequence (SSRs) for genetic research are a good choice to reveal the mechanism of genetic genes in plants [13, 14]. RNA-sequencing is an effective tool to obtain SSRs with higher rate of transferability for nonsequenced genomes and non-model organisms $[15,16]$. It has been demonstrated that SSRs obtained from one species could be used to detect diversity in related species and even in other genera of the same family [17, 18]. SSR has been widely used in genetic mapping, relationship studies [19], cultivar identification [20, 21] and analysis of plant genetic diversity [22]. Hitherto SSR markers have been widely applied to plant research, such as Zea mays [23], Citrullus lanatus [24], Triticum aestivum and the genus Cerasus species [25].

In previous studies, there have been many molecular marker studies on Carex, which also included SSR method. M'Baya et al. [26] utilized 14 SSRs isolated in Carex kobomugi to test genetic structure of Carex hebes and Carex breviculmis and possessed a high level of genetic variation. Meanwhile, other useful molecular markers also used to investigate the diversity between Carex species. Liu et al. [3] reported 30 SSR markers from C. moorcroftii, which provide an available tool to explore the genetic structure and phylogenetic evolution. Starr et al. [27] found that matK barcoding could distinguish between $47 \%$ of Carex materials and clearly distinguish phylogenetic diversity relationships in $\mathrm{NJ}$ evolutionary trees. Ning et al. [28] proved that ISSR molecular markers are a powerful tool for studying the genetic diversity of Carex. They all found a result that the diversity between Carex species were complex. Nagasawa et al. [29] found that the evolutionary relationships of Carex populations could result in a low level of polymorphism in the populations. Man et al. [30] compared genetic variation and population structure of 15 C.breviculmis populations in Korea and indicated that gene flow was extensive. Although certain progress has been made in studying Carex genetics using molecular markers, there are few studies on SSR molecular markers based on Illumina RNA-sequencing. And the number of materials used are less in the previous research. Moreover, compared to the studies of crops and model plants, molecular studies of Carex are still lacking. It is of great economic value to research the relationships and diversity among Carex species at present.

In our previous study, we used the single-molecule long read sequencing method to investigate the transcriptional regulating network of Carex breviculmis in response to shade tolerance [31]. In the present study, we further explored the SSRs based on the previous Illumina sequencing dataset. The aims of this study were: (1) to enrich Carex transcriptome information and get a better understanding of the function categories from the annotated genes, (2) to develop SSR markers and validate their polymorphism levels, (3) to investigate the genetic background between Carex germplasms.

\section{Results \\ Illumina sequencing and de novo assembly of transcriptome}

The transcriptome of Carex breviculmis was sequenced using the HiSeq ${ }^{\mathrm{TM}} 2000$ platform. A total of $43.67 \mathrm{~Gb}$ clean data was obtained. The clean data of each sample reached $6.32 \mathrm{~Gb}$, and the Q30 base percentage was above $94.03 \%$. A total of 36,403 unigenes were assembled, of which there were 12,657 unigenes with a length of more than $1 \mathrm{~kb}$. The N50 of the unigene was 2016, indicating a high assembly integrity.

\section{Gene annotation based on different databases}

Based on homology analysis of the sequence, 11,629 unigenes (31.95\%) were divided into three main GO categories and 50 sub-categories. The GO classification includes 'Cellular process', 'Metabolic process', 
and 'Single-organism process'. (Fig. 1a). The 'Cell' was the largest subgroup of cellular components group. The next largest group was 'Cell part,' followed by 'Organelle', 'Nucleoid' and 'Macromolecular complex'. The categories 'Catalytic activity' and 'Binding' among ten different molecular function categories for the Carex unigenes were also abundant. According to the KOG database, 11,871 unigenes were categorized into 25 functional groups and $20.52 \%$ of unigenes were annotated to 'General function' cluster. 'Post-translational modification', 'Protein turnover' and 'Chaperones' (1303 unigenes, 10.98\%) was the next largest group and followed by 'Signal transduction mechanisms' (1111 unigenes, 9.36\%). Alternatively, 'Nuclear structure' (46 unigenes, 0.39\%), 'Extracellular structures' (30 unigenes, $0.25 \%$ ). Unigenes in 'Cell motility' (4 unigenes, $0.03 \%$ ) groups were significantly less than the above three groups (Fig. 1b). Based on the KEGG database, a total of 8440 unigenes were found, including 40 biological pathways belonging to five large groups (Cellular Processes, Genetic Information Processing, Environmental Information Processing, Metabolism, and Organismal Systems). Three main pathways included Ribosome (499, 5.91\%), Carbohydrate metabolism (452, 5.36\%), and Biosynthesis of amino acids $(357,4.23 \%)$ were in these 50 pathways (Fig. 1c).

Based on the database of NCBI non-redundant nucleotide, the E-value distribution revealed that $23.00 \%$ of unigenes yielded significant hits (Fig. 2a), and approximately $35.00 \%$ of unigenes exhibited greater than $80 \%$ identity (Fig. 2b). NR protein sequences alignment results revealed that $21.69 \%$ could be aligned with Ananas comsous, $10.10 \%$ could be aligned with Elaeis guineensis, and $8.03 \%$ could be aligned with Phoenix dactylifera (Fig. 2c).

Frequency and distribution of SSRs in the transcriptome A total of 36,403 unigenes were scanned using the MISA software and 8776 SSR loci were detected (Table 1). The

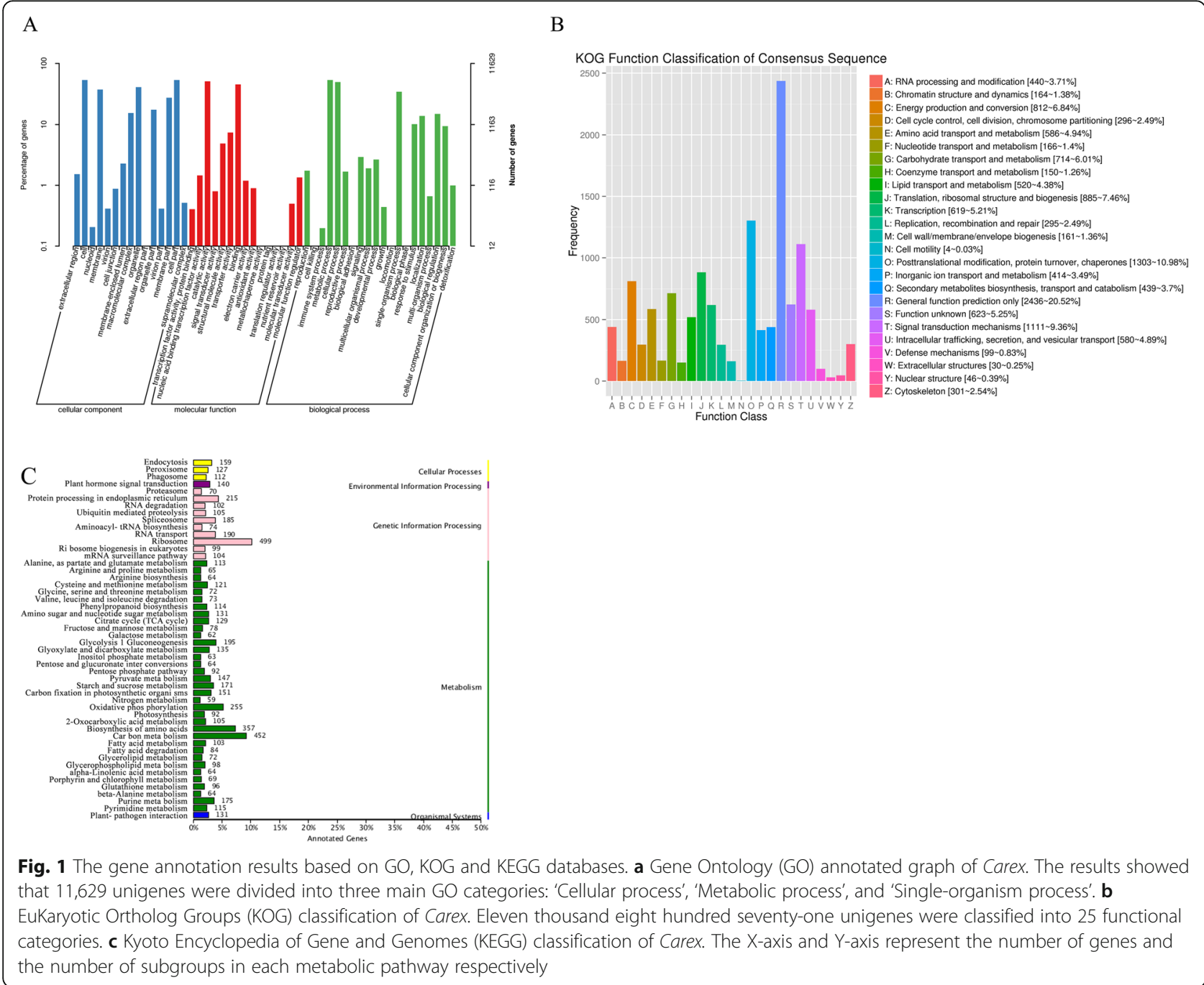


SSR locus in the transcriptome has six types and the number of each repeat type varies greatly. The single repeat motif accounting for $64.93 \%$ ranked the most abundant type, whereas the hexa-nucleotides accounting for $1.11 \%$ was the least abundant type. The most abundant Di-nucleotide repeats were AC/GT $(8138 ; 18.02 \%)$ and followed by AT/AT (1339; 3.10\%), AC/GT (827; 1.83\%). The most plenty Tri-nucleotide repeats were AAG/CTT (1008; 2.23\%) and followed by ATC/ATG (454; 1.01\%). Meanwhile, the most affluent tetra-repeat motif types were AAAG/CTTT $(87 ; 0.21 \%)$. The number of hexaand penta-nucleotide motifs were $399(0.88 \%)$ and 377 (0.83\%), respectively (Fig. 3).

\section{Development and transferability assessment of novel}

\section{SSRs}

We designed and synthesized 96 pairs to amplify 11 phenotypic difference Carex materials (Table S1). Among them, 42 (43.75\%) pairs can amplify several bands and have high polymorphism. The primers
Table 1 Prediction of SSRs out of our transcript datasets of Carex breviculmis

\begin{tabular}{ll}
\hline Item & Number \\
\hline Total number of sequences examined & 36,403 \\
Total size of examined sequences (bp) & $41,724,615$ \\
Total number of identified SSRs & 8776 \\
Number of SSR containing sequences & 6018 \\
Number of sequences containing more than one SSR & 504 \\
Number of SSRs present in compound formation & 20 \\
Mono nucleotide & 5699 \\
Di nucleotide & 1873 \\
Tri nucleotide & 582 \\
Tetra nucleotide & 63 \\
Penta nucleotide & 15 \\
Hexa nucleotide & 20 \\
\hline
\end{tabular}

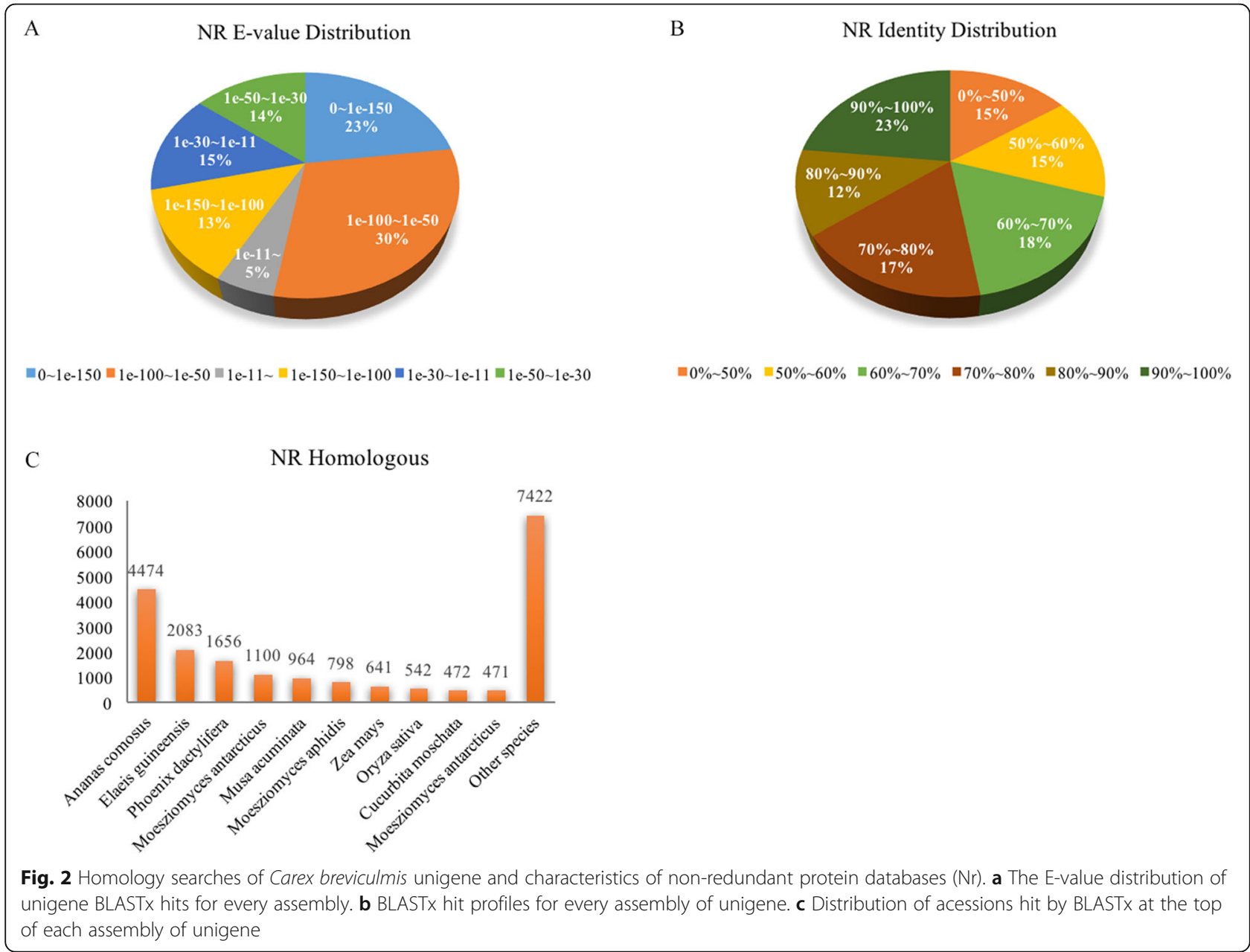


indicated good transferability between different Carex species. The number of not amplified bands accounts for $15.6 \%$ and others showed low polymorphism or no polymorphism.

\section{Genetic diversity statistics}

In the set of 42 SSRs, we recognized 180 marker alleles across the 79 accessions. Among the 42 SSRs, PIC value ranged from 0.133 and 0.494 , with an average of 0.259 . SSRs displayed wide genetic variation among accessions. The genetic diversity between Carex materials was investigated by cluster analysis, principal component analysis. The polymorphic ratio was $100 \%$ and an average of 4.3 primers was amplified per primer. The number of observed alleles $(\mathrm{Na})$, the number of effective alleles $(\mathrm{Ne})$, Nei's (1973) gene diversity $(H)$, and the Shannon information index (I) were 2.000, 1.376, 0.243, and 0.391, respectively, indicating that the genetic diversity between the Carex accessions was high. We also calculated the genetic distance between accessions (Table S2), which ranged from 0.222 to 1.000 . The genetic distance average value was 0.548 .

\section{Cluster analysis of Carex based on SSR markers}

In order to reveal the classification information of Carex species, we obtained the allele frequency according to our original data. Instead of using a priori classification such as provenance or taxonomy, we used NJ, PCoA and UPGMA cluster analysis and combined the results to explore the genetic information and classification of all accessions.

Principal coordinate (PCoA) results showed that Axis 2 separated and generated two genetically differentiated groups of Carex accessions (Fig. 4). The first principal component accounts for $29.6 \%$ and the second principal component accounts for $19.8 \%$.

Based on the distance calculation method of Shered Allele, the Neibor-Joining phylogenetic analysis divided 79 Carex accessions into three groups (Fig. 5). The Group I has a total of 22 materials and $C$. jaluensis, $C$. dimorpholepis, $C$. agglomerata2 are grouped into very similar categories. Also the commercial plant materials from New Zealand are grouped into one category in Group I, including $C$. virgata, C. frosted curls, C. solandi, C. oshimensis'Evergold', C. feather falls, C. buchananii, C. everst, C. diapacea, C. testacea, C. lomandra longifolla limetuff. The Group II includes 24 materials, C. subpediformis and $C$. jaluensis are the most similar accessions. The Group III includes 33 materials and most of which are from all over China, but also four materials are from Germany and North America. It is worth mentioning that the C. breviculmis collected from various provinces in China are all classified into this group.

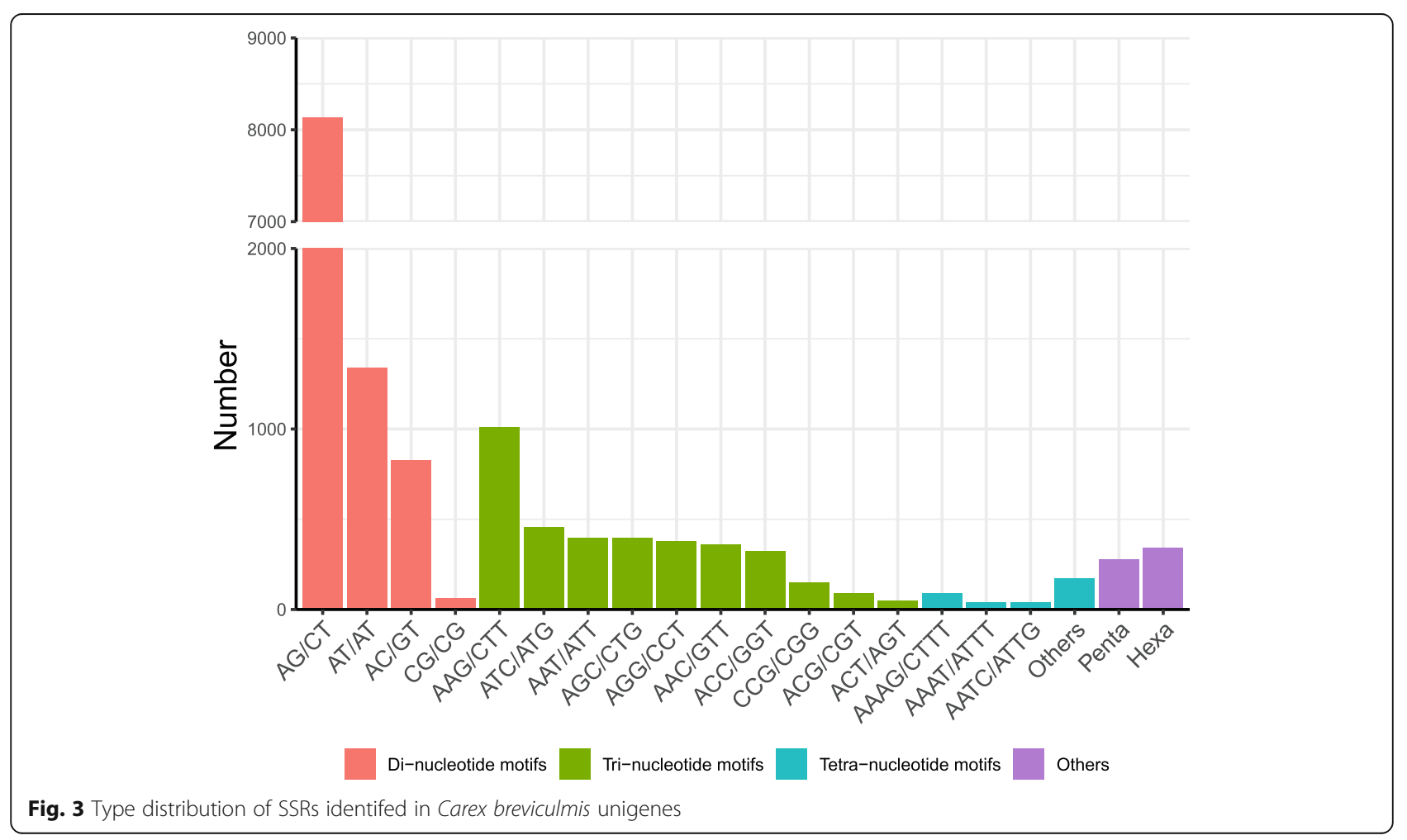




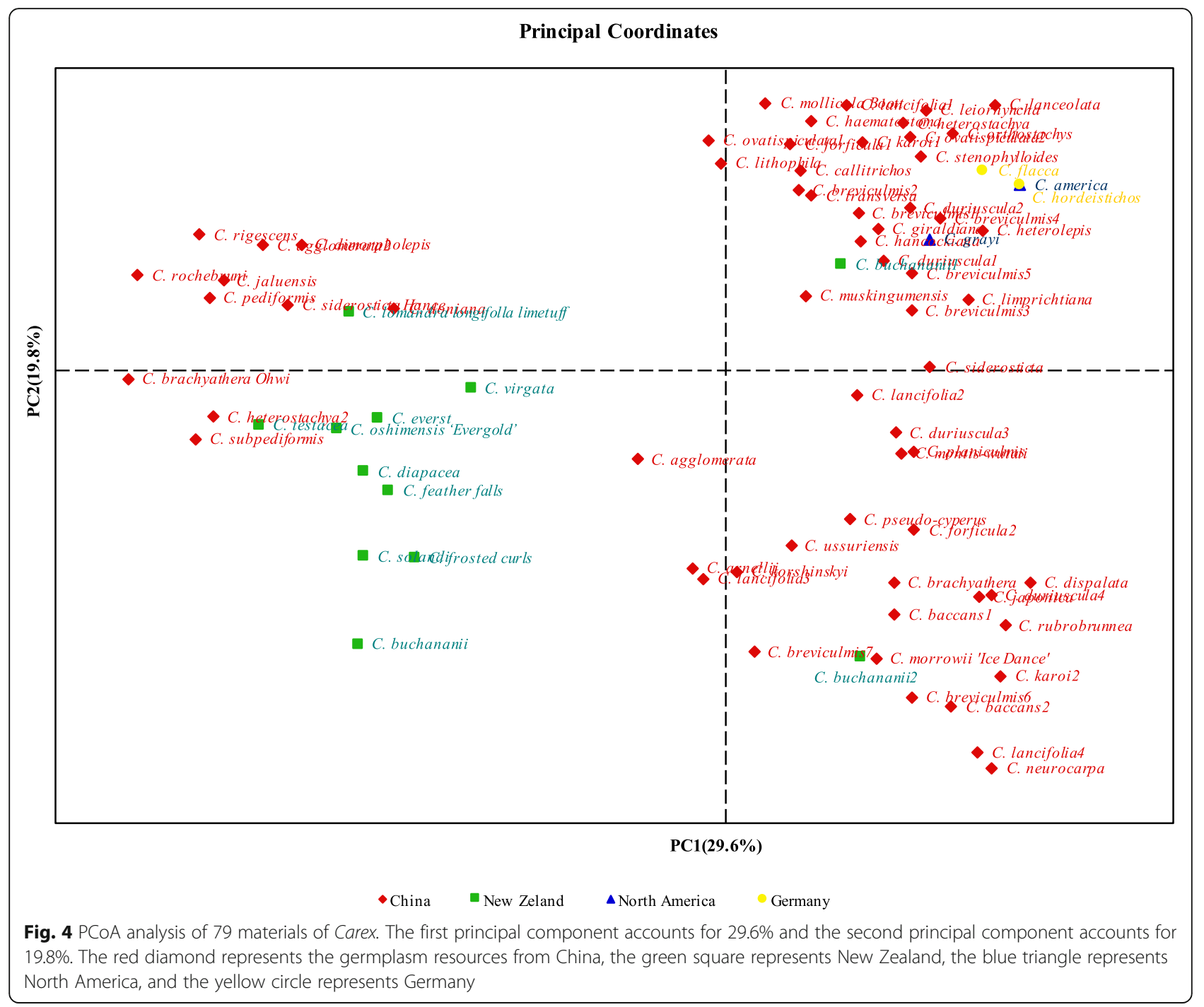

Based on the SSR original data, Dice coefficient method was used to calculate the similarity. A total of 79 materials were clustered using the UPGMA method (Fig. 6). The similarity between genotypes was $0.070 \sim$ 0.786. Through UPGMA clustering, 79 accessions of germplasm resources were divided into two major groups. C. jaluensis was assigned to a separate group. The remaining 78 domains of Carex accessions were divided into two subgroups, and C. agglomerata, C. dimorpholepis and $C$. lomandra longifolla limetuff were classified into one group. While nine accessions from New Zealand were clustered into one group when the genetic distance was 0.42 , but $C$. lomandra longifolla limetuff was not clustered into this group. Although it was not clustered with the accessions from New Zealand, the genetic similarity was relatively high. Regarding the collection sources of Carex, there is a certain degree of gene exchange between Carex germplasm from China and New Zealand, Germany and North America. However, the resources cannot be divided completely by region in general. The Sorensen-Dice correlation coefficient was $r=0.941$, indicating that the clustering results were reliable.

\section{AMOVA analysis of Carex accessions based on different methods}

In order to evaluate the genetic differences between these germplasms, we calculated the $\mathrm{F}_{\mathrm{ST}}$ values between all pairs of accessions for the two levels studied (origin and genetic classification). Through different analysis of source, the AMOVA indicated that $88 \%$ of the total genetic variation of 79 accessions was within populations, and $12 \%$ was among populations. The results of AMOVA analysis showed that some 


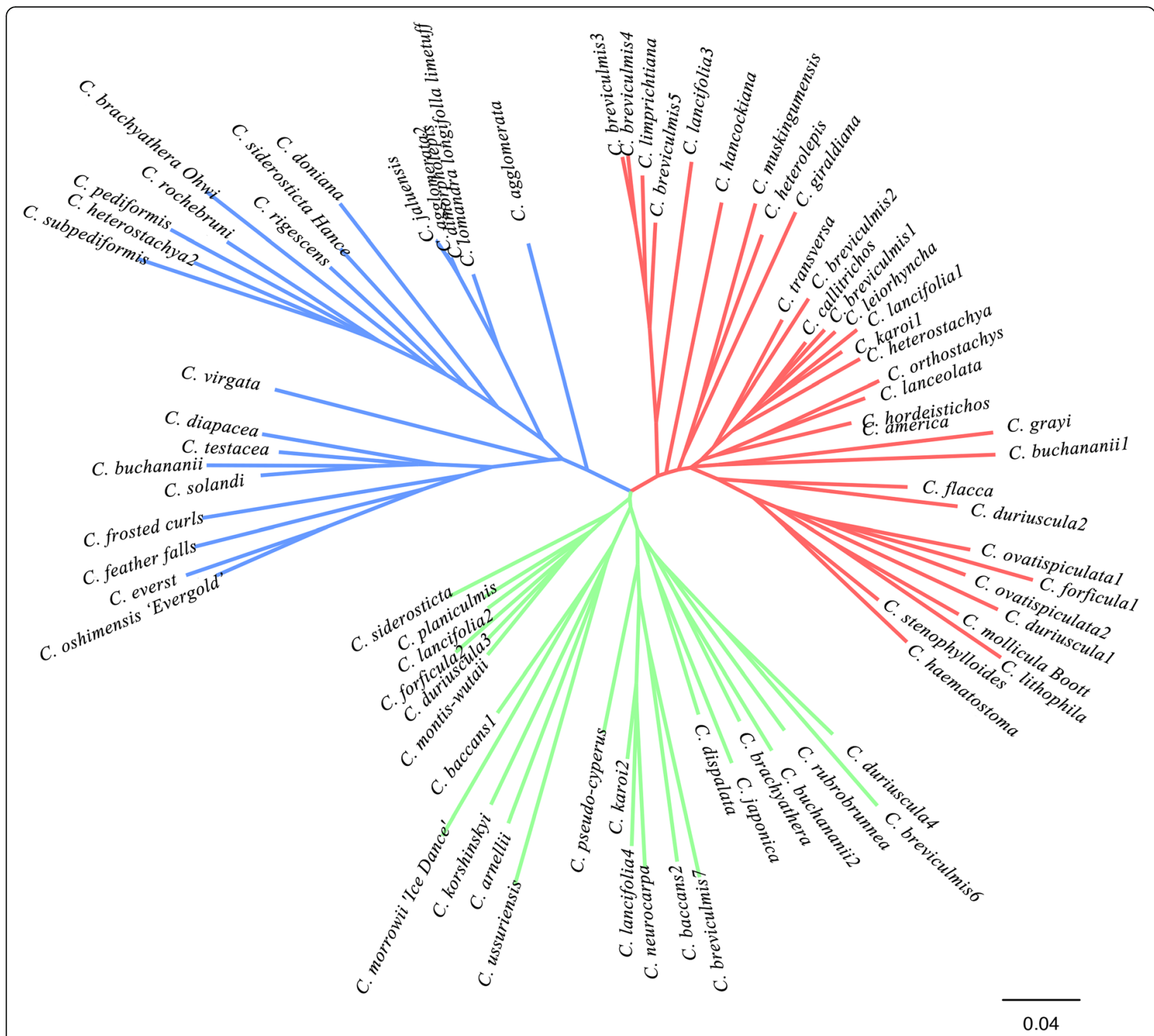

Fig. $5 \mathrm{~N}$-J phylogenetic tree of 79 Carex accessions. N-J tree included three major clusters, including Group I (22 accessions) which is blue, II (24 accessions) green and III (33 accessions) red

subspecies have large variations within countries, which was consistent with the above results of accessions from different countries. While the results of AMOVA analysis based on NJ cluster analysis showed that $89 \%$ within populations (Table 2). $\mathrm{F}_{\mathrm{ST}}$ values and probability $\mathrm{P}$ (rand $\geq$ data) were 0.117 and 0.052 respectively.

\section{Fingerprint}

Results showed that 42 pairs of SSR markers can be efficient in differentiating between 79 accessions, and a fingerprint map, which can distinguish more varieties at a time, was established (Table S3).

\section{Discussion}

Our previous work reported the transcriptional regulation network of $C$. breviculmis in response to shade stress using single-molecule long-read sequencing [31]. In the present study, we utilized the Illumina RNA-seq data in order to generate SSR markers and thus to explore the genetic diversity of other 79 Carex accessions. We released a large quantity of expressed gene sequences (36,403 unigene sequences). In order to get a better understanding of the function categories of Carex genes, we searched the GO, KOG, KEGG pathway mapping databases. A total of 20,948 unigenes annotation results were obtained. The results showed that $57.54 \%$ of 


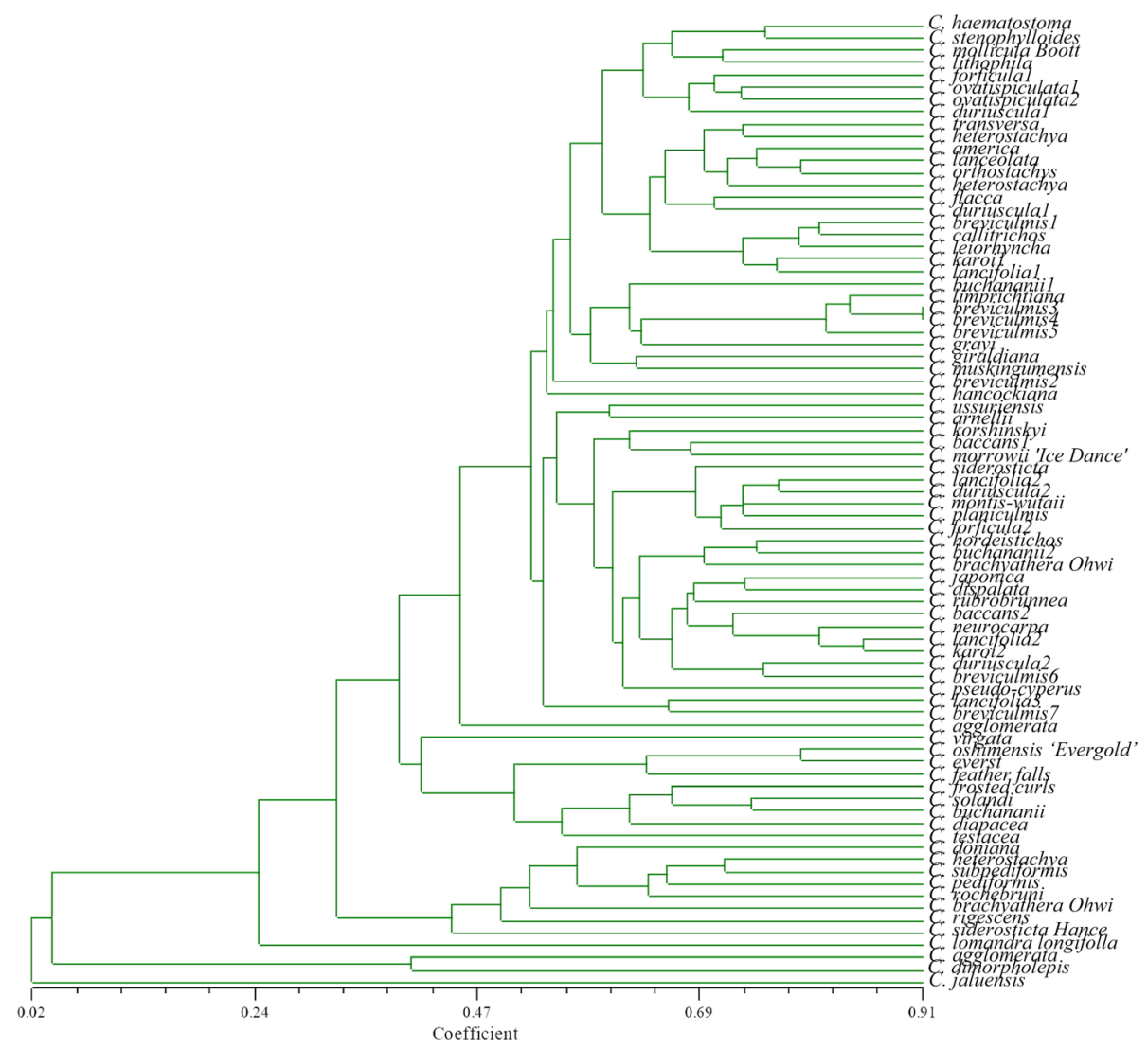

Fig. 6 UPGMA clustering analysis of 79 Carex

the genes were successfully annotated, reflecting the high transcriptome diversity of Carex. Gene Ontology is a global classification system of the gene function, classifies the characteristics of genes into groups of 'biological processes', 'cellular components' and 'molecular functions' [32]. KOG analysis was devoted to classify orthologous groups for eukaryotic complete genomes. KEGG analysis is one of the most frequently used method to analyze gene metabolic products and its putative

Table 2 AMOVA analysis of Carex accessions

\begin{tabular}{lllllll}
\hline & Source & df & SS & MS & Est. Var. & $\%$ \\
\hline Regions & Among Pops & 3 & 181.719 & 60.573 & 3.667 & $12 \%$ \\
& Within Pops & 75 & 2082.687 & 27.769 & 27.769 & $88 \%$ \\
& Total & 78 & 2264.405 & & 31.436 & $100 \%$ \\
\multirow{4}{*}{ Taxa } & Among Pops & 2 & 217.629 & 108.814 & 3.162 & $11 \%$ \\
& Within Pops & 76 & 2046.777 & 26.931 & 26.931 & $89 \%$ \\
& Total & 78 & 2264.405 & & 30.093 & $100 \%$ \\
\hline
\end{tabular}

Note: AMOVA results for 4 regions of origin and 3 taxa. Fst values and probability $\mathrm{P}$ ( $\mathrm{ran} \geq$ data) were as follows: Region of Origin $(0.117 ; 0.052)$, Taxa $(0.105 ; 0.001)$

Df Degrees of Freedom, SS Sum of squares, MS Mean squares, Est. Var. estimated variance, $\%$ proportion of genetic variability functions [33]. As in the results of $\mathrm{Li}$ et al. [34], the $\mathrm{GO}$ database classifies annotation information into three categories: biological processes, cellular components, and molecular functions. The largest subcategory was 'binding', while followed by 'catalytic activity'. We also found that the KEGG pathway had the largest group of genes belonging to the metabolism category, while the genetic information processing category was the second largest group. Based on NR alignment results, $21.69 \%$ of sequences could be aligned with those of Ananas comsous. It was indicated that $C$. breviculmis and Bromeliaceae family members has closest relationship with respect to protein alignment. Ananas comsous belongs to Bromeliaceae family, while $C$. breviculmis belongs to Cyperaceae. Considering the taxonomy of plants, $A$. comsous and $C$. breviculmis seem to be genetically distant species. The reason for the unexpected protein alignment could be the lack of data on Cyperaceae-related species in the current NR database. The results show that it is necessary and urgent to update the genetic database of this genus.

Gene structure analysis was performed based on the unigene library, in which SSR analysis obtained a total of 8776 SSR markers. Among the detected sites, 5699 
single nucleotide repeats accounting for the total number of SSR sites of $64.93 \%$. Followed by trinucleotides and dinucleotides (1873 and 582, respectively, 21.37 and 6.63\%), which are different from the results that three Nucleotide repetitive sequences are the most abundant repetitive units in radish, with a frequency of 52\% [35]. It indicated that the specificity of SSR sites is different in plants. Among all the repeat motifs of 303 functional primer pairs, AC/GT (18.02\%) is the most abundant dinucleotide repeat in Carex breviculmis.

Although there are a lot of researches on Carex, more researches are on a certain kind or a restricted property of it. However, the genetic background and genetic relationship are unclear, especially between and among Carex species. It restricted the introduction of Carex resources, rational selection of hybrid parents, and genetic engineering breeding. In particular, studies on the genetic level of Carex have not revealed evolutionary issues such as genetic relationship.

In this research, we found that 42 SSR primer pairs amplified 178 alleles in 79 Carex accessions, with an average of 4.3 alleles per microsatellite. Compared with previous studies, the ratio of polymorphic 100\% were higher than the study of C. sempervirens used RAPD markers [36]. It indicted that the development efficiency and polymorphism of SSR markers developed by transcriptome sequencing are more efficient than RAPD markers. We also found that PIC value in this research was lower than the value of 0.83 reported by Ning et al. [28] and similar to the value obtained by Nagasawa et al. [29]. PIC values are used to measure the level of population polymorphism in other plants and they depend on the accessions tested. Locus polymorphism can be divided into high level (PIC >0.5), medium level $(0.5>$ PIC >0.25) and low level (PIC < 0.25 ) according to their information content [37]. In case of the number of Carex and molecular markers used in Ning's study were small, and all of the Carex accessions were from the same region in the Shandong Province. Secondly, ISSR used by Ning et al. [28] is probably more efficient than using specie specific SSR markers. The PIC value is similar to Nagasawa et al. [29] research results that 20 of EST-SSR markers developed with low polymorphism in C. angustisquama population and King et al. [38] results that identified 11 microsatellite loci from Carex macrocephala. Due to the species' population dynamics, the low genetic polymorphism were obtained, rather than to null alleles at the developed markers. Carex germplasms are considered to have the lower PIC values which identified in this study appeared to reflect this low diversity and the low genetic variation in Carex resulted from the species history, and not from the characteristics of the used markers.
In cluster analysis, we used a combination of $\mathrm{NJ}$, UPGMA and PCoA analysis methods. Firstly, by the reason of the growth environment is similar and the nine accessions are all commercial materials introduced and domesticated in New Zealand, the germplasm from New Zealand are consistent in the classification to one group. Same with the research of Ning et al. [28], the results of the species from the same area could be classified into one category, which is correlated with geographical distribution and environmental conditions. Secondly, because of similar genetic backgrounds and morphological characteristics or their common geographic origin, $C$. grayi and C. hordeisticho of NJ Group III had obvious characteristics. Also C. breviculmis and C. lancifolia from China were clustered into Group III of closely related species, which is consistent with the traditional classification method. The morphology of these two Carex species are very similar, and even hard to distinguish, but it can be achieved using the clustering method of molecular markers.

There was a gene exchange with the Chinese test materials during the cultivation process that $C$. buchananii1 and $C$. buchananii2 are mixed with Chinese materials to varying degrees. The materials from Germany and North America could not be classified into a single category due to the sample size, but we found that the collection place of the materials would have a certain impact on the classification of Carex. Furthermore, through the analysis of principal components, it can be seen that Carex plants are not clearly classified. Perhaps they still have large genetic differences among plants of the same genus and no definite result. Therefore, further studies involving more foreign germplasms are still needed in order to better interpret this phenomenon.

In addition, the PCoA based on these genotypic data clearly showed that there was an obvious genetic differentiation among Carex accessions. The clustering results of PCoA and UPGMA were partially consistent and showed significant differences among all the analyzed accessions. The result of fingerprint is valuable for Carex species with extremely similar appearance that don't be easily distinguished. Previous studies have showed that SSR markers can be used for plant species diversity analysis and fingerprint development [39]. For example, they were used in establishing the fingerprint of 36 Chinese jujube cultivars with 12 pairs of newly developed SSR primers [40], and eight SSR loci were further recommended as a core marker set for fingerprinting of the tea plant [41]. In this study, we concluded that different combinations of primer pairs could be used to distinguish different species of Carex, which is of great significance in the selection of hybrids for breeding new varieties. 


\section{Conclusion}

The transcriptomic analysis shed new light on the function categories from the annotated genes and will facilitate future gene functional studies. The genetic background analysis indicated that gene flow was extensive among 79 Carex species. These markers can be used to assess genetic diversity and to investigate the evolutionary history of Carex and related species, as well as to serve as a guide in future breeding projects.

\section{Methods}

\section{Plant material and DNA extraction}

A total of 79 Carex accessions were collected from different locations, including 64 from China, 11 from New Zealand, 2 from the North America, and 2 from Germany. The 64 accessions from China were sampled from the Beijing Botanical Garden, Mount Tai, Xi'an Botanical Garden, Hebei, Shanghai, and the base of the Beijing Academy of Agricultural and Forestry Sciences (Table 3). We have acquired a permission to purchase or collect all of the plant materials under the guidelines of local organizations. The formal identification of the samples was carried out by two plant taxonomists of our group, Dr. Chen and Dr. Xun, referring to the Flora Reipublicae Popularis Sinicae and based on the commercial introductions. Genomic DNA was extracted from healthy young shoots by mixing 10 individual plants of each culture separately using the CTAB method [42]. Using $1 \%$ agarose gel electrophoresis to examine the quality and integrity of genomic DNA. DNA concentration was determined through with the NanoDrop 2000 spectrophotometer (NanoDrop, Thermo Fisher Scientific, Wilmington, DE, USA). The extracted DNA was diluted with $\mathrm{ddH}_{2} \mathrm{O}$ to $20 \mathrm{ng} / \mathrm{mL}$ and used as the template and inventory for PCR amplification. The extracted DNA was stored at $-20{ }^{\circ} \mathrm{C}[43]$.

\section{Transcriptome sequencing, de novo assembly and function annotation}

Transcriptome sequencing of Carex breviculmis was performed by Biomarker Technologies for RNA extraction, and sequencing was performed on the HiSeq 2000 platform [31]. In this study, TRINITY Version 2.5.1 was used to detect contigs from the same transcript, to determine the distance between contigs and connect them together to obtain contigs with inextensible ends [44]. TGICL software was used to splice these single genes and remove their redundancy to obtain non-redundant single genes. Using the BLAST (http://blast.ncbi.nlm.nih.gov/Blast.cgi) searches (e-value $<1 \mathrm{E}-5$ ) of the assembled unigenes [45, 46]. The sequence is compared to the following databases: Gene Ontology (GO), Eukaryotic Orthologous Groups of proteins (KOG), the Kyoto Encyclopedia of Genes and
Genomes (KEGG), and National Center for Biotechnology Information for non-redundant proteins (NR).

SSRs of the transcriptome were identified using MISA [47]. Using Primer3 (http://primer3.sourceforge.net/ releases.php) for each SSR primer design. SSR loci contained motifs of two to six nucleotides in size were preferentially selected. The other principle of selection was that six minimum repeating units of di-nucleotide, five tri-nucleotides, and four of all higher order motifes, including tetra-nucleotide, penta-nucleotide, and hexanucleotide.

\section{Identification of SSRs, and primer design}

Amplification of SSR markers was carried out using DNA of 11 Carex species with large phenotypic differences. Ninety-six SSR primers, which were identified in Carex breviculmis using RNA-seq, were randomly selected for this research. All primers were synthesized by RuiBo Biotech. Among the ninty-six synthesized pairs of primers, 42 pairs had higher levels of polymorphisms and were used in further experimental research (Table 4). All reactions were conducted using BIO-RAD T100 Thermal Cycler ${ }^{\mathrm{rm}}$. The PCR reaction system were carried out in a total volume of $10 \mu \mathrm{L}$, including $5 \mu \mathrm{L}$ of $2 \times$ Taq Master Mix, $0.2 \mu \mathrm{L}$ of primer, $2 \mu \mathrm{L}$ of genomic DNA, and $2.6 \mu \mathrm{L}$ of $\mathrm{ddH}_{2} \mathrm{O}$. The thermal profile used for amplifications consisted of $10 \mathrm{~min}$ of initial denaturation at $94{ }^{\circ} \mathrm{C}$, followed by 34 cycles of $30 \mathrm{~s}$ at $94{ }^{\circ} \mathrm{C}, 30 \mathrm{~s}$ at the optimized annealing temperature, $60 \mathrm{~s}$ of extension at $72{ }^{\circ} \mathrm{C}$, and a final extension of $5 \mathrm{~min}$ at $72{ }^{\circ} \mathrm{C}$. Used $8.0 \%$ non-denatured polyacrylamide gels with a 100-bp ladder marker (TRANSGEN BIOTECH, Beijing, China) to separate successful PCR products and visualized by silver staining [48]. DNA of 79 Carex individuals was amplified using SSR primers to analyze genetic diversity. Clear bands on the gel images under the light lamp were observed, with or without bands as (1) or (0).

\section{Genetic diversity analysis}

A binary qualitative data matrix was constructed and analyzed using POPGENE Version 1.3.2. Genetic diversity of different materials was determined by calculating the percentage of polymorphic bands (PPB), the effective number of alleles $(\mathrm{Ne})$, observed number of alleles $(\mathrm{Na})$, Nei's gene diversity $(\mathrm{H})$, and Shannon's information index (I). The polymorphic information (PIC) of a band was calculated by the following formula: $\mathrm{PIC}=1-\sum_{j}^{i}$ $P_{i j}{ }^{2}$ ( $\mathrm{P} i$ and $\mathrm{P} j$ are the frequencies of the $i$ th and $j$ th alleles at one locus). We used the software NTSYS Version 2.1 [49] to construct a cluster analysis description of selected group Q pattern based on Nei's genetic 
Table 3 The 79 Carex materials information

\begin{tabular}{|c|c|c|}
\hline Code & Name & Origin \\
\hline 1 & C. haematostoma & Yunnan, China \\
\hline 2 & C. mollicula Boott & Beijing, China \\
\hline 3 & C. transversa & Beijing, China \\
\hline 4 & C. forficulal & Beijing, China \\
\hline 5 & C. breviculmis 1 & Beijing, China \\
\hline 6 & C. breviculmis2 & Beijing, China \\
\hline 7 & C. ovatispiculatal & Beijing, China \\
\hline 8 & C. leiorhyncha & Beijing, China \\
\hline 9 & C. lithophila & Beijing, China \\
\hline 10 & C. ovatispiculata2 & Beijing, China \\
\hline 11 & C. heterostachya & Beijing, China \\
\hline 12 & C. karoil & Beijing, China \\
\hline 13 & C. callitrichos & Beijing, China \\
\hline 14 & C. lancifolia1 & Beijing, China \\
\hline 15 & C. limprichtiana & Beijing, China \\
\hline 16 & C. duriuscular & Beijing, China \\
\hline 17 & C. breviculmis3 & Beijing, China \\
\hline 18 & C. breviculmis4 & Beijing, China \\
\hline 19 & C. stenophylloides & Beijing, China \\
\hline 20 & C. breviculmis5 & Beijing, China \\
\hline 21 & C. duriuscula2 & Beijing, China \\
\hline 22 & C. giraldiana & Beijing, China \\
\hline 23 & C. muskingumensis & Beijing, China \\
\hline 24 & C. heterolepis & Beijing, China \\
\hline 25 & C. lanceolata & Beijing, China \\
\hline 26 & C. orthostachys & Beijing, China \\
\hline 27 & C. hancockiana & Beijing, China \\
\hline 28 & C. siderosticta & Beijing, China \\
\hline 29 & C. Iancifolia2 & Beijing, China \\
\hline 30 & C. ussuriensis & Beijing, China \\
\hline 31 & C. planiculmis & Beijing, China \\
\hline 32 & C. arnellii & Beijing, China \\
\hline 33 & C. Iancifolia3 & Shandong, China \\
\hline 34 & C. japonica & Beijing, China \\
\hline 35 & C. montis-wutaii & Hebei, China \\
\hline 36 & C. korshinskyi & Xi'an, China \\
\hline 37 & C. forficula2 & Shandong, China \\
\hline 38 & C. duriuscula3 & Beijing, China \\
\hline 39 & C. baccans 1 & Xi'an, China \\
\hline 40 & C. dispalata & Xi'an, China \\
\hline 41 & C. brachyathera & Xi'an, China \\
\hline 42 & C. agglomerata & Xi'an, China \\
\hline 43 & C. duriuscula4 & Xi'an, China \\
\hline 44 & C. rubrobrunnea & Xi'an, China \\
\hline
\end{tabular}


Table 3 The 79 Carex materials information (Continued)

\begin{tabular}{|c|c|c|}
\hline Code & Name & Origin \\
\hline 45 & C. morrowii 'Ice Dance' & Xi'an, China \\
\hline 46 & C. breviculmis6 & Xi'an, China \\
\hline 47 & C. baccans2 & Beijing, China \\
\hline 48 & C. neurocarpa & Shaanxi, China \\
\hline 49 & C. breviculmis7 & Shandong, China \\
\hline 50 & C. lancifolia4 & Shandong, China \\
\hline 51 & C. pseudo-cyperus & Shandong, China \\
\hline 52 & C. karoi2 & Xi'an, China \\
\hline 53 & C. agglomerata2 & Beijing, China \\
\hline 54 & C. doniana & Xi'an, China \\
\hline 55 & C. heterostachyaz & Xi'an, China \\
\hline 56 & C. rochebruni & Xi'an, China \\
\hline 57 & C. dimorpholepis & Xi'an, China \\
\hline 58 & C. pediformis & Beijing, China \\
\hline 59 & C. brachyathera Ohwi & Beijing, China \\
\hline 60 & C. rigescens & Beijing, China \\
\hline 61 & C. subpediformis & Shanghai, China \\
\hline 62 & C. jaluensis & Shanghai, China \\
\hline 63 & C. siderosticta Hance & Shanghai, China \\
\hline 64 & C. buchananii1 & Shanghai, China \\
\hline 65 & C. buchananii2 & ODERINGS, New Zealand \\
\hline 66 & C. virgata & ZELANDIA, New Zealand \\
\hline 67 & C. frosted curls & ODERINGS, New Zealand \\
\hline 68 & C. solandi & ZELANDIA, New Zealand \\
\hline 69 & C. oshimensis 'Evergold' & ZELANDIA, New Zealand \\
\hline 70 & C. feather falls & ZELANDIA, New Zealand \\
\hline 71 & C. buchananii & ODERINGS, New Zealand \\
\hline 72 & C. everst & ODERINGS, New Zealand \\
\hline 73 & C. diapacea & ODERINGS, New Zealand \\
\hline 74 & C. testacea & ODERINGS, New Zealand \\
\hline 75 & C. lomandra longifolla limetuff & ODERINGS, New Zealand \\
\hline 76 & C. grayi & North America \\
\hline 77 & C. america & North America \\
\hline 78 & C. flacca & Germany \\
\hline 79 & C. hordeistichos & Germany \\
\hline
\end{tabular}

distances [50]. Afterwards, the unweighted pairwise method of arithmetic mean is used to analyze the parameters.

\section{Cluster analysis and AMOVA analysis of 79 accessions} The similarity of Carex was evaluated using NTSYS Version 2.1. According to the similarity matrix of SSR data set, the UPGMA clustering method was used to construct the dendrogram [51]. Using PowerMarker version 3.25 and MEGA 5, the unweighted phylogenetic tree was constructed based on the Dice dissimilarity matrix between 79 individuals [52, 53]. Based on the Bootstrap function of FreeTree program, the robustness of phylogenetic trees was evaluated through 1000 repeated bootstrap analyses [54]. Principal coordinate analysis (PCoA) was performed according to the 
Table 4 The SSRs primer information identified for validation in this study

\begin{tabular}{|c|c|c|c|c|}
\hline Primer & \#Gene_ID & SSR & Forward primer( $\left(5^{\prime}-3^{\prime}\right)$ & Reverse primer(5'-3') \\
\hline CAREX001 & F01.1 & $(\mathrm{AG}) 6$ & CACTGGAGAACCTAGCGACC & TTGTACAAGGTCCAGGGAGAA \\
\hline CAREX006 & F01.141 & $(\mathrm{TC}) 7$ & CGTTCCCCGTITCTTCTCT & GCCGTCTTCTTTGAAAACCA \\
\hline CAREX008 & F01.166 & $(\mathrm{TC}) 9$ & CAGTATGGTGGTGAGAGCGA & CACAGACCGAACCTAACAACAA \\
\hline CAREX010 & F01.180 & $(\mathrm{TC}) 7$ & GCTTCGTTGTCTACTAGCCCC & GACCAATCCAGCTGAGAAGC \\
\hline CAREX012 & F01.240 & (CT)15 & CCACACAGCTTATTGCTTGC & TGATAGGTGGGTTTCTTGCC \\
\hline CAREX015 & F01.339 & $(A G) 10$ & TGATTITTCCAATGCGTGAA & TGCCAGTTGAATCTCAGTGC \\
\hline CAREX016 & F01.3449 & $(\mathrm{AG}) 7$ & CCCCTTCAATTCAATGCTGT & GCAATGAGAGGGAAAATCCA \\
\hline CAREX017 & F01.3529 & $(\mathrm{GA}) 10$ & TGAATCATTGAAGGAGAGAGCA & GGTTGTTGCAAAGGAAGAGC \\
\hline CAREX018 & F01.357 & $(\mathrm{AG}) 7$ & TITCTAACCCTITATCGCCG & AAAATTGCCTGGAGGAGGAG \\
\hline CAREX019 & F01.364 & (AT)6 & ATCATGCGGCCAAGATAAAG & CAAGCAGGGGTGGAGAATAG \\
\hline CAREX023 & F01.463 & (TC)6 & TAGTGCTGCCAGAAAGAGCA & AAACTCAACCCGAAAAGGCT \\
\hline CAREX024 & F01.501 & $(\mathrm{CT}) 8$ & GTCCCCAAAACCTCTGTAGC & TGCTTGTTGTTCGCTTCATC \\
\hline CAREX025 & F01.5079 & $(\mathrm{AG}) 10$ & TGCATGCAGCTGGAATAGAG & CTCCAAATCCGAACTATCCG \\
\hline CAREX026 & F01.5099 & $(\mathrm{CT}) 6$ & AGCCTCTCTCTCTCTCCGCT & GCAAAAATGCCTGAGTGGAT \\
\hline CAREX030 & F01.608 & $(\mathrm{CT}) 14$ & CGCCTCTTCATCGATCTTTC & GCCCCAATAATGGAGAGGAT \\
\hline CAREX031 & F01.612 & $(\mathrm{CT}) 9$ & CCCAATCTCCAAAGAGCAAA & AGAACGAGACCTGGAGCTGA \\
\hline CAREX037 & F01.735 & (AT)6 & GCAGGGTTGTTGAAGGTTTG & TTGTGGATGCAAAACAGCAT \\
\hline CAREX040 & F01.789 & $(\mathrm{TG}) 17$ & TGCTGTTCTCATGGCTTCTG & CCTTTCATTITGATGAGGCAA \\
\hline CAREX041 & F01.792 & $(\mathrm{AG}) 7$ & CAAAAAGGAAGCGAAAGGAA & TGAGAGAGGAGATCGGAGGA \\
\hline CAREX042 & F01.809 & $(\mathrm{TA}) 8$ & ACAAAAGAGCTCGCTGGAAA & TCTGATTGCTGCTCAACTATCTC \\
\hline CAREX048 & F01.1070 & $(\mathrm{GCT}) 5$ & CTTCATTTCCGCCTCTCTTG & GCAATCATTATGCAATGCCA \\
\hline CAREX044 & F01.854 & $(\mathrm{CT}) 6$ & ACACAGGGACAAGCCGATAG & CAACAAGCACAACAATAACCA \\
\hline CAREX045 & F01.855 & $(C T) 6$ & CCAAAAGATATCATCATCTCCGA & TGAGCAGCGATCTCTITGAA \\
\hline CAREX046 & F01.930 & $(\mathrm{AT}) 6$ & TCTIITTGCCAAGATGGTGA & GTGCCAAGCATCAATCAGAA \\
\hline CAREX050 & F01.151 & (CTC)6 & TCATTAGCTGGTCGCTTCCT & CATGCCCATTGTTCTTGATG \\
\hline CAREX053 & F01.3450 & $(\mathrm{CTG}) 5$ & ACCCAGTGATCGTACTTCGG & AGATTCAATTTCCACCGTCG \\
\hline CAREX054 & F01.3506 & $(\mathrm{ACC}) 5$ & TCAACCCGCTACACCTAACC & ACACGCTCCAGGTCAGAGAT \\
\hline CAREX055 & F01.3514 & $(\mathrm{AAC}) 5$ & ССАСАССТССТАСТССТССА & CTCCCCGTTGAAGTTGTTGT \\
\hline CAREX060 & F01.5072 & (ATT)5 & TACGCCATTGTCAACGAAAA & GCACGAGACACCTGAACACA \\
\hline CAREX062 & F01.5103 & $(\mathrm{CAG}) 5$ & AGGCACCACAAGATCCAAAC & GCTCCCATCCATACAGCTTC \\
\hline CAREX064 & F01.511 & $(C A C) 9$ & TCCTCAGGTAGCGAAAGCAG & TACCTTAATTGCGGAATCGG \\
\hline CAREX069 & F01.52166 & $($ ATA $) 5$ & GTACCTGCCCTGGATTCTGA & GGCGCTITTACCAAATCAAA \\
\hline CAREX070 & F01.592 & $($ ATT)6 & ATTCATCAGGCAATTCTGGC & GGCTAAACCAACTCCTGCAC \\
\hline CAREX072 & F01.675 & $(\mathrm{GAT}) 5$ & CTGATCTCAAAAGGCGAAGG & CACGTAGGGATCACCCAATC \\
\hline CAREX073 & F01.719 & $(A G A) 5$ & TAAAATGAAGGGCGAGGATG & CACTCCGTGATGATGTGGTC \\
\hline CAREX076 & F01.785 & (GAT)8 & TGAAGAAGGGCCTGGTACTG & AACCACCAGATCCCACAGTC \\
\hline CAREX083 & F01.1429 & $(A G A) 5$ & GGGAATCACAGACAAAGGGA & ATACTGGCAGAACCAATGGC \\
\hline CAREX086 & F01.11991 & $(\mathrm{CTT}) 6$ & TACGGTACAGGCGTCTCTCA & CAGAAGCAACGCAACACATT \\
\hline CAREX094 & F01.9172 & $($ GAAT)5 & ATGGTTTCTGATTTCCTGCG & GGGGTCAAATGTAGTTGCAGA \\
\hline CAREX095 & F01.9272 & $($ TAAT) 8 & CCTTCAAAAGAGAACCGAGC & TGTCGCCTITGTGAGCATAG \\
\hline CAREX096 & F01.17075 & $(\mathrm{TCTCT}) 5$ & GACTCCGACTCCAGTTGAGC & TCGAGGAGCTGTCCTTGAAT \\
\hline CAREX097 & F01.21485 & $(\mathrm{CCTCT}) 5$ & CCCATCATCGATCAATCACA & GGAACAACGATCGGAAAGAA \\
\hline
\end{tabular}


anastomotic differences between binary genotypic profiles using the GenAlEx 6.5 program based on the pairwise distance matrix [55]. Both distance and covariance were standardized.

The tratified genetic variation between and within geographic groups was analyzed using Analysis of Molecular Variance (AMOVA) [56]. F statistic was used to analyze the genetic differentiation between populations. Both analyses were performed using the GenAlEx 6.5 software [55].

\section{Supplementary Information}

The online version contains supplementary material available at https://doi. org/10.1186/s12870-020-02792-8.

Additional file 1: Table S1. The information of 11 Carex materials to select primers.

Additional file 2: Table S2. The Nei's genetic distance between Carex species.

Additional file 3: Table S3. The fingerprint of 79 Carex materials.

\section{Abbreviations}

AFLP: Amplified fragment length polymorphism; AMOVA: Analysis of molecular variance; GO: Gene ontology; $H$ : The gene diversity index; I: The Shannon information index; ISSR: Inter-simple sequence repeat; KEGG: Kyoto encyclopedia of genes and genomes; KOG: EuKaryotic ortholog groups; Na: The average number of observed alleles; Ne: The effective alleles; NJ: Neighbor-joining; NR: NCBI non-redundant protein databases; PCoA: Principal coordinate analysis; PCR: Polymerase chain reaction; PIC: The polymorphic information content; RAPD: Random amplified polymorphic; RFLP: Restriction fragment length polymorphism; SRAP: Sequence related amplified polymorphism; SSR: Simple sequence repeat

\section{Acknowledgements}

We acknowledge the Biomarker Corporation (Beijing, China) for the facilities and expertise of Illumina platform for libraries construction and sequencing. We also thank the Editage Company (www.editage.com) for language editing.

\section{Authors' contributions}

ZC and XF conceived the study and designed the experiments. LL performed the experiment. KT, PT and LL analyzed the data with suggestions by JW, HZ, CH, CC, LX, and WG. LL and KT wrote the manuscript. All authors read and approved the final version of the manuscript.

\section{Funding}

This research was supported by the Beijing Natural Science Foundation (No.6204039), National Natural Science Foundation of China (31901397), and Scientific Funds of Beijing Academy of Agriculture and Forestry Sciences to $\mathrm{KT}$. Each of the funding bodies granted the funds based on a research proposal. They had no influence over the experimental design, data analysis or interpretation, or writing the manuscript.

\section{Availability of data and materials}

The Illumina NGS reads generated in this study has been submitted to the BioProject database of National Center for Biotechnology Information (PRJNA488506).

\section{Ethics approval and consent to participate}

The materials used in this study were collected by ourselves. And we complied with all relevant institutional, national and international guidelines and specify the appropriate permissions obtained. We also have acquired a permission to collect all of the plant materials.

\section{Consent for publication}

Not applicable.

\section{Competing interests}

The authors declare that they have no competing interests.

\section{Author details}

${ }^{1}$ College of Grassland Science, Beijing Forestry University, Beijing 100083, China. ${ }^{2}$ Beijing Research and Development Center for Grass and

Environment, Beijing Academy of Agriculture and Forestry Sciences, Beijing 100097, China. ${ }^{3}$ Beijing Chaoyang Foreign Language School, Beijing 100000 , China. ${ }^{4}$ Shaanxi Engineering Research Center for Conservation and Utilization of Botanical Resources, Xi'an Botanical Garden of Shaanxi Province (Institute of Botany of Shaanxi Province), Shaanxi 710000, China. ${ }^{5}$ Department of Plant Biology, University of California, Davis, Davis, CA, USA.

Received: 18 December 2019 Accepted: 9 December 2020

Published online: 06 January 2021

\section{References}

1. Pedersen MAT, Nowak MD, Brysting AK, Elven R, Bjorå CS. Hybrid origins of Carex rostrata var. borealis and C. stenolepis, two problematic taxa in carex section vesicariae (cyperaceae). PloS One. 2016;11(10):1.

2. Gillespie EL, Pauley AG, Haffner ML, Hay NM, Estep MC, Murrell ZE. Fourteen polymorphic microsatellite markers for a widespread limestone endemic, Carex eburnea (Cyperaceae: Carex sect. Albae). Appl Plant Sci. 2017;5(8): 1700031.

3. Liu W, Zhou Y, Liao H, Zhao Y, Song Z. Microsatellite primers in Carex moorcroftii (Cyperaceae), a dominant species of the steppe on the QinghaiTibetan plateau. Am J Bot. 2011;98(12):e382-4.

4. Ye YR, Wang WL, Zheng CS, Fu J, Liu HW. Evaluation of cold resistance of four wild Carex speices. Chin J Appl Ecol. 2017;28(1):89-95.

5. Wang Y, Yang H, Li X, Wang W, Bai C, Liu G. Carex jianfengensis (Carex sect. Rhomboidales, Cyperaceae), a New Species from Hainan, China. Plos One. 2015;10(9):e0136373.

6. Léveillé-Bourret É, Starr JR, Ford BA. Why are there so many sedges? Sumatroscirpeae, a missing piece in the evolutionary puzzle of the giant genus Carex (Cyperaceae). Mol Phylogenet Evol. 2018;119:93-104.

7. Benítez-Benítez C, Escudero M, Rodríguez-Sánchez F, Martín-Bravo S, Jiménez-Mejías P. Pliocene-Pleistocene ecological niche evolution shapes the phylogeography of a Mediterranean plant group. Mol Ecol. 2018;27(7): 1696-713.

8. Míguez M, Gehrke B, Maguilla E, Jiménez-Mejías P, Martín-Bravo S. Carex sect. Rhynchocystis (Cyperaceae): a Miocene subtropical relict in the Western Palaearctic showing a dispersal-derived Rand Flora pattern. J Biogeography. 2017.

9. Martín-Bravo S, Jiménez-Mejías P, Villaverde T, Escudero M, Hahn M, Spalink D, Roalson EH, Hipp AL, Benítez-Benítez C, Bruederle LP, et al. A tale of worldwide success: Behind the scenes of Carex (Cyperaceae) biogeography and diversification. J Syst Evol. 2019;57(6).

10. Group GC. Making Carex monophyletic (Cyperaceae, tribe Cariceae): a new broader circumscription. Bot J Linn Soc. 2015;179(1).

11. Group TGC, Jiménez-Mejías $P$, Hahn M, Lueders K, Starr JR, Brown BH, Chouinard BN, Chung KS, Escudero M, Ford BA. Megaphylogenetic specimen-level approaches to the Carex (Cyperaceae) phylogeny using ITS, ETS, and matK sequences: implications for classification. Syst Bot. 2016.

12. Jones CJ, Edwards KJ, Castaglione S, Winfield MO, Sala F, Wiel CVD, Bredemeijer G, Vosman B, Matthes M, Daly A. Reproducibility testing of RAPD, AFLP and SSR markers in plants by a network of European laboratories. Mol Breed. 1997;3(5):381-90.

13. Hokanson SC, Szewc-McFadden AK, Lamboy WF, McFerson JR. Microsatellite (SSR) markers reveal genetic identities, genetic diversity and relationships in a Malus x domestica borkh. Core subset collection. Theor Appl Genet. 1998; 97(5-6):671-83.

14. Escudero M, Vargas P, Arens P, Ouborg NJ, Luceno M. The east-west-north colonization history of the Mediterranean and Europe by the coastal plant Carex extensa (Cyperaceae). Mol Ecol. 2010;19(2):352-70.

15. Zhang Z, Xie W, Zhao Y, Zhang J, Wang Y. EST-SSR marker development based on RNA-sequencing of E. sibiricus and its application for phylogenetic relationships analysis of seventeen Elymus species. BMC Plant Biol. 2019; 19(1).

16. Pan L, Huang T, Yang Z, Tang L, Cheng Y, Wang J, Ma X, Zhang X. EST-SSR marker characterization based on RNA-sequencing of Lolium multiflorum and cross transferability to related species. Mol Breed. 2018;38(6). 
17. Alisoltani A, Ebrahimi S, Azarian S, Hematyar M, Rafiei F. Parallel consideration of SSRs and differentially expressed genes under abiotic stress for targeted development of functional markers in almond and related Prunus species. Sci Hortic-Amsterdam. 2016;198:462-72.

18. Kalia RK, Rai MK, Kalia S, Singh R, Dhawan AK. Microsatellite markers: an overview of the recent progress in plants. Euphytica. 2011;177(3):309-34.

19. Senthilvel S, Shaik M, Anjani K, Shaw RK, Kumari P, Sarada C, Kiran BU. Genetic variability and population structure in a collection of inbred lines derived from a core germplasm of castor. J Plant Biochem Biot. 2017;26(1): 27-34.

20. Chapman MA, Hvala J, Strever J, Matvienko M, Kozik A, Michelmore RW, Tang S, Knapp SJ, Burke JM. Development, polymorphism, and cross-taxon utility of EST-SSR markers from safflower (Carthamus tinctorius L.). Theor Appl Genet. 2009;120(1):85-91.

21. Zhou S, Wang C, Frazier TP, Yan H, Chen P, Chen Z, Huang L, Zhang X, Peng $Y$, Ma $X$. The first Illumina-based de novo transcriptome analysis and molecular marker development in Napier grass (Pennisetum purpureum). Mol Breed. 2018;38(7):95.

22. Nie G, Tang L, Zhang Y, Huang L, Ma X, Cao X, Pan L, Zhang X, Zhang X Development of SSR markers based on transcriptome sequencing and association analysis with drought tolerance in perennial grass Miscanthus from China. Front Plant Sci. 2017;8.

23. Choi JK, Sa KJ, Park DH, Lim SE, Ryu SH, Park JY, Park KJ, Rhee HI, Lee M, Lee JK. Construction of genetic linkage map and identification of QTLs related to agronomic traits in DH population of maize ( Zea mays L.) using SSR markers. Genes Genom. 2019:41(6):667-78.

24. Che KP, Xu Y, Liang $C Y$, Gong GY, Weng ML, Zhang HY, Jin DM, Wang $B$. AFLP fingerprint and SCAR marker of watermelon core collection. Acta Bot Sin. 2003;45(6):731-5.

25. Kato S, Matsumoto A, Yoshimura K, Katsuki T, Iwamoto K, Kawahara T, Mukai Y, Tsuda Y, Ishio S, Nakamura K, et al. Origins of Japanese flowering cherry (Prunus subgenus Cerasus) cultivars revealed using nuclear SSR markers. Tree Genet Genomes. 2014;10(3):477-87.

26. Mbaya JBMJ, Hoffmann AA. Genetic structure of Carex species from the Australian Alpine region along elevation gradients: patterns of reproduction and gene flow. Int J Plant Sci. 2013;174(2):189-99.

27. Starr JR, Naczi RF, Chouinard BN. Plant DNA barcodes and species resolution in sedges (Carex, Cyperaceae). Mol Ecol Resour. 2010;9(s1):151-63.

28. Ning H, Wang W, Zheng C, Li Z, Zhu C, Zhang Q. Genetic diversity analysis of sedges ( Carex spp.) in Shandong, China based on inter-simple sequence repeat. Biochem Systematics Ecol. 2014;56:158-64.

29. Nagasawa K, Setoguchi H, Maki M, Goto H, Fukushima K, Isagi Y, Sakaguchi S. Development and characterization of EST-SSR markers for Carex angustisquama (Cyperaceae), an extremophyte in solfatara fields. Appl Plant Sci. 2018;6(10):e01185-n/a.

30. Man KH, Lee HY, Mishra SN, Hong WH. Genetic variation and population structure of Carex breviculmis (Cyperaceae) in Korea. J Plant Biol. 2000;43(3): 136-42.

31. Teng K, Teng WJ, Wen HF, Yue YS, Guo WE, Wu JY, Fan XF. PacBio singlemolecule long-read sequencing shed new light on the complexity of the Carex breviculmis transcriptome. BMC Genom. 2019;20(1):789.

32. Zhou F, Wang Z, Yu G, Shi B, Wang X, Qiang H, Gao H. Development and Characterization of Simple Sequence Repeat (SSR) Markers Based on RNASequencing of Medicago sativa and In silico Mapping onto the $M$. truncatula Genome. PLoS One. 2014:9(3):e92029.

33. Liu Z-J, Torre S, Tattini M, Brunetti C, Fineschi S, Fini A, Ferrini F, Sebastiani F. RNA-Seq analysis of Quercus pubescens leaves: De novo transcriptome assembly, annotation and functional markers development. PLoS One. 2014 9(11):e112487

34. Li MA, Long RC, Feng ZR, Liu FQ, Sun Y, Zhang K, Kang JM, Wang Z, Cao SH. Transcriptome analysis of salt-responsive genes and SSR marker exploration in Carex rigescens using RNA-seq. J Integr Agr. 2018;17(1): 184-96.

35. Wang S, Wang X, He Q, Liu X, Xu W, Li L, Gao J, Wang F. Transcriptome analysis of the roots at early and late seedling stages using Illumina pairedend sequencing and development of EST-SSR markers in radish. Plant Cell Rep. 2012;31(8):1437-47.

36. Yu F-H, Kruesi BO, Schneller JJ, Schuetz M, Tang M, Wildi O. Positive correlation between vegetation dissimilarity and genetic differentiation of Carex sempervirens. Flora. 2009:204(9):651-7.
37. Yan D, Zhao X, Cheng Y, Ma X, Huang L, Zhang X. Phylogenetic and diversity analysis of Dactylis glomerata subspecies using SSR and IT-ISJ markers. Molecules. 2016;21(12):1459.

38. King MG, Roalson EH. Isolation and characterization of 11 microsatellite loci from Carex macrocephala (Cyperaceae). Conserv Genet. 2009;10(3):531-3.

39. Bharti R, Kumar S, Parekh MJ. Development of genomic simple sequence repeat (gSSR) markers in cumin and their application in diversity analyses and cross-transferability. Ind Crop Prod. 2018;111:158-64.

40. Ma LY, Kong DC, Liu HB, Wang SQ, Li YY, Pang XM. Construction of SSR fingerprint on 36 Chinese jujube cultivars. Acta Horticulturae Sinica. 2012; 39(04):647-54

41. Tan LQ, PengM, Xu LY,Wang LY, Chen SX, Zou Y, Qi GN, Cheng $H$. Fingerprinting 128 Chinese clonal tea cultivars using SSR markers provides new insights into their pedigree relationships. Tree Genet Genomes. 2015; 11(5):1-12.

42. Kim C, Jung J, Choi H-K. Molecular identification of Schoenoplectiella species (Cyperaceae) by use of microsatellite markers. Plant Syst Evol. 2012;298(4): 811-7.

43. Baruah J, Gogoi B, Das K, Ahmed NM, Sarmah DK, Lal M, Bhau BS. Genetic diversity study amongst Cymbopogon species from NE-India using RAPD and ISSR markers. Ind Crop Prod. 2017;95:235-43.

44. Haynsen MS, Vatanparast M, Mahadwar G, Zhu D, Moger-Reischer RZ, Doyle JJ, Crandall KA, Egan AN. De novo transcriptome assembly of Pueraria montana var. lobata and Neustanthus phaseoloides for the development of eSSR and SNP markers: narrowing the US origin(s) of the invasive kudzu. BMC Genomics. 2018;19(1):439.

45. Altschul SF, Madden TL, Schäffer AA, Zhang J, Zhang Z, Miller W, Lipman DJ. Gapped BLAST and PSI-BLAST: a new generation of protein database search programs. Nucleic Acids Res. 1997;25:3389-402.

46. Evangelistella C, Valentini A, Ludovisi R, Firrincieli A, Fabbrini F, Scalabrin S, Cattonaro F, Morgante M, Mugnozza GS, Keurentjes JJB, et al. De novo assembly, functional annotation, and analysis of the giant reed (Arundo donax L.) leaf transcriptome provide tools for the development of a biofuel feedstock. Biotechnol Biofuels. 2017;10:138.

47. Beier S, Thiel T, Münch T, Scholz U, Mascher M. MISA-web: a web server for microsatellite prediction. Bioinformatics. 2017;33(16):2583.

48. Ndjiondjop MN, Semagn K, Gouda AC, Kpeki SB, Tia DD, Sow M, Goungoulou A, Sie M, Perrier X, Ghesquiere A, et al. Genetic variation and population structure of Oryza glaberrima and development of a mini-core collection using DArTseq. Front Plant Sci. 2017;8.

49. Tohme J, Gonzalez DO, Beebe S, Duque MC. AFLP analysis of gene pools of a wild bean core collection. Crop Sci. 1996;36(5):1375-84.

50. Nie M, Bolland HR. Spermatogenesis, chromosomes and sex determination of four Rhipicephalus species (Acari: Ixodidae) from East Africa. Genetica. 1978;48(3):233-8.

51. Dawyndt $P$, Meyer HD, Baets BD. UPGMA clustering revisited: a weightdriven approach to transitive approximation; 2006

52. Kumar S, Tamura K, Nei M. MEGA: molecular evolutionary genetics analysis software for microcomputers. Comput Appl Bio. 1994;10(2):189-91.

53. Liu K, Muse SV. PowerMarker: an integrated analysis environment for genetic marker analysis. Bioinformatics. 2005;9:2128-9.

54. Hampl V, Pavlícek A, Flegr J. Construction and bootstrap analysis of DNA fingerprinting-based phylogenetic trees with the freeware program FreeTree: application to trichomonad parasites. Int J Syst Evol Microbiol. 2001:51(Pt 3):731.

55. Peakall R, Smouse PE. GenAlEx 6.5: genetic analysis in excel. Population genetic software for teaching and research-an update. Bioinformatics. 2012;28(28):2537-9.

56. Jia H, Yang H, Sun P, Li J, Zhang J, Guo Y, Han X, Zhang G, Lu M, Hu J. De novo transcriptome assembly, development of EST-SSR markers and population genetic analyses for the desert biomass willow, Salix psammophila. Sci Rep. 2016;6(1):39591.

\section{Publisher's Note}

Springer Nature remains neutral with regard to jurisdictional claims in published maps and institutional affiliations. 